\title{
Mitozofia polska księdza Huszny
}

\author{
Jarosław Tomasiewicz (iD https://orcid.org/0000-0001-9750-5256 \\ Instytut Historii \\ Uniwersytet Śląski w Katowicach \\ e-mail: jaroslaw.tomasiewicz@us.edu.pl
}

\section{Abstract \\ Polish mythosophy by Rev. Andrzej Huszno}

Andrzej Huszno (1892-1939) was one of the most interesting - although marginal - clergyman in the Second Polish Republic. He tried to create an esoteric version of the Catholicism based on the allegoric interpretation of religious symbols, the cyclical idea of time and "temporalization" of eschatology. The perennialist idea of the common root of all religions determined Huszno's interests in Slavic pagan beliefs.

Keywords: esotericism, perennialism, Neopaganism

Słowa kluczowe: ezoteryzm, perenializm, neopoganizm

Do opisania twórczości ks. Andrzeja Huszny (1892-1939) - jednego z najciekawszych polskich herezjarchów ${ }^{1}$ - najwłaściwszym wydaje się mało popularne pojęcie „mitozofii”. Użyte bodaj po raz pierwszy w 1993 r. przez Marię Boużyk w znaczeniu „poznania poprzez mit”, Henryk Kiereś definiuje je szerzej jako „znajomość, zdolność do układania, jak i umiejętność odczytywania zawartej w mitach mądrości"2. Zaryzykować można wszakże stwierdzenie, że na potoczne rozumienie pojęcia największy wpływ wywarł swą Mitozofia sarmacka Jany P. Waluszko ${ }^{3}$, którego tropami podążyło środowisko neosłowiańskich mitozofów związanych z portalem Taraka.

${ }^{1}$ Określenie Tomasza Sikorskiego: T. Sikorski, Herezjarcha. Andrzej Huszno (1892-1939): życiedziatalność - poglady, Warszawa-Radzymin 2018.

${ }^{2}$ M. Boużyk, Mitozofia czy bankructwo rozumu, „Człowiek w Kulturze” 1993, nr 1, s. 139-158; H. Kiereś, Mit, [w:] Powszechna encyklopedia filozofii, t. 7, aut. haseł M. Aleksandrowicz et al., zespół red. A. Maryniarczyk et al., Lublin 2006, s. 279-280.

3 J.P. Waluszko, Sarmacja, Mielec 1999. 
Redaktor portalu Wojciech Jóźwiak wyjaśnia, że mitozofowie „ze strzępów legend [...] wyciągają daleko idące wątki i wnioski; daleko - bo aż do horyzontu tego, co się w ogóle sensownie da o mitach powiedzieć”, gdyż „, [t]o, co ma do powiedzenia nauka, ma dość ograniczoną na tym polu efektywność"4. W rezultacie - tu przywołuje przykład Mircei Eliadego - „mitozoficzne analizy [...] są [...] tak [w ten sposób - J.T.] głoszonymi religiami ich autorów"5. Interpretacja mitu wobec niemożności zweryfikowania danych staje się faktycznie jego tworzeniem. Amerykański entuzjasta mitozofii Scott Orrell Davis idzie jeszcze dalej, odróżniając mądrość od wiedzy i głosząc, że w micie ukryte są „parabole mądrości wskazujące drogę ku transcendentnemu urzeczywistnieniu czyjegoś bytu"6. Tak też uważał ks. Huszno, którego mitozofia łączyła polską tradycję mesjaniczną z koncepcjami zagranicznych ezoteryków i elementami neopogańskimi w barwną, choć niespójną całość. Był zbuntowanym duchownym rzymskokatolickim, który w 1924 r. założył w Zagłębiu Dąbrowskim niezalegalizowany Polsko-Katolicki Kościół Narodowy (dalej- PKKN) ${ }^{7}$.

U źródeł husznańskiego rozłamu tkwiła głęboka niezgoda z doktryną i działalnością Kościoła rzymskokatolickiego. Krytyka katolicyzmu była wieloaspektowa, dotyczyła zarówno oficjalnej doktryny i organizacji Kościoła, jak i codziennych postaw i zachowań duchowieństwa. Podstawowy jednak, jak się zdaje, zarzut Huszny odnosił się do niezrozumienia przez katolicyzm istoty duchowości - Kościół rzymskokatolicki jawił mu się jako starzec, który zatracił swe posłannictwo ${ }^{8}$. Z tego powodu katolikom w ich - jak twierdził - ,prostactwie religijnym” umykało głębokie, ukryte znaczenie religii, przez co np. „materjalnie czyli cieleśnie pojmują Boga", a ich wiara $\mathrm{w}$ transsubstancjację przypomina kanibalizm ${ }^{10}$. Zarazem przeciwstawianie przez katolików ducha materii sprawiało, że życie doczesne postrzegali jako niosące potępienie ${ }^{11}$. W związku z tym, wedle Huszny, „Kościół rzymski odrywa myś1 człowieka od realnych trosk życia [...], a przenosi ją w krainę urojenia"12. Kościół rzymskokatolicki stał się „kościołem umarłych"13.

Huszno już w 1917 r. pisał, że błędem zasadniczym wszystkich Kościołów chrześcijańskich było utożsamienie religijności z kultem zewnętrznym ${ }^{14}$. Chcąc odkryć istotę religii, inspiracji szukał u teozofów, którzy wydobywali „ukryte znaczenie”

${ }^{4}$ W. Jóźwiak, W głąb mitologii Stowian, https://tarakablog.wordpress.com/2008/11/18/w-glab-mitologii-slowian/ [dostęp: 8.08.2015].

5 Ibidem.

${ }^{6}$ S.O. Davis, Mythosophy: The Wisdom of Myth. A Defense of Perennial Thought in Post-modern Times, mps, dysertacja doktorska,University of West Florida, 2001, s. 156.

${ }^{7}$ Szczegółowy opis działalności A. Huszny zob. T. Sikorski, op. cit., s. 9-127.

${ }^{8}$ Dlaczego zerwaliśmy z Rzymem?, „Głos Ziemowida” [dalej: GZ] 1925, nr 13, s. 2 [uwaga: w tytułach artykułów z „Głosu Ziemowida”, ze względu na częste ich podobieństwo lub nawet identyczność, nie jest stosowana skrócona forma przypisu].

9 Współczesne pogaństwo, GZ 1925, nr 17, s. 1.

${ }^{10}$ Boże Ciało, GZ 1925, nr 14, s. 2.

${ }^{11}$ Kościól a kwestja społeczna, GZ 1924, nr 2, s. 4.

12 Poradnik rolniczy, GZ 1925, nr 13, s. 6.

${ }^{13}$ Kościól a kwestja społeczna, GZ 1924, nr 2, s. 4.

${ }^{14}$ A. Huszno, Syn Człowieczy, Kraków 1917, s. 44. 
symboli i idei. Helena Bławatska porównywała egzoteryczną stronę religii do „zasłony oddzielającej tabernakulum od miejsc zebrań ludzi”, ale zapewniała, że „,z]a pośrednictwem [ezoterycznych - J.T.] czterech wysokich władców [...] nasze pięć zmysłów może przenikać ukryte prawdy natury"15. Rozpoznanie ukrytego przed profanami, duchowego sensu otaczającej ich rzeczywistości prowadziło do idei uświęcenia doczesności. Według Bławatskiej cała materia była przeniknięta boskim pierwiastkiem, ,jedyną, jednorodną, boską Substancją-Pryncypem [...] uśpioną w każdym atomie" ${ }^{16}$. Pierwiastek ów pozwalał bytom materialnym ewoluować, osiągać doskonałość, tak więc „każdy tzw. Duch jest już [...] ucieleśnionym lub przyszłym człowiekiem [...] [O]d wyższego archanioła aż do [...] niższej klasy duchowych istot wszyscy okazują się ludźmi, żyjącymi eony wcześniej”"17. Takie podejście - negujące opozycję Ducha i Materii - pozwalało zdaniem ezoteryków przezwyciężyć sprzeczność między religią i nauką ${ }^{18}$.

Idąc tym śladem, PKKN głosił, że świat materialny ma charakter względny jako emanacja bytu doskonałego - Boga ${ }^{19}$. W „Głosie Ziemowida” często pojawiały się aluzje, że rzeczywistość to tylko pozór, ,[k]oło, po którem się toczy złuda naszego życia i bytu" ${ }^{20}$, miraż ${ }^{21}$. Poznanie prawdy zarezerwowane było dla wybranych ,za sprawą Ducha św. mocą Bożą, mocą tego Ducha, który przenika wszechświat”22. Huszno zapewniał: „My mamy dar widzenia, dar poznania tajemnic Bożych”23. PKKN głosił, że istota kapłaństwa polega na „świętem wtajemniczeniu”, a nie na święceniach kapłańskich ${ }^{24}$.

Huszno daleki był jednak od manichejskiej pogardy materii. Wnioskował, że skoro światem rządzi Bóg, a nie szatan, to Królestwo Boże musi być na ziemi²5, a zbawienie oznacza doskonałe szczęście doczesne człowieka ${ }^{26}$. „Głos Ziemowida” zapewniał, że Kościół polskokatolicki będzie się troszczyć o życie nie tylko pozagrobowe, ale też ziemskie ${ }^{27}$. W rzeczywistości PKKN szedł dużo dalej, nadając doczesności wymiar metafizyczny, ba - utożsamiając świat duchowy z materialnym. „Dla nas religią jest życie”, głosił², gdyż „[c]złowiek jako [...] duch jest [...] wieczny, ale

${ }^{15}$ H. Bławatska, Doktryna tajemna, t. 1, Warszawa 1996, s. 183.

16 Ibidem, t. 2, s. 171-172.

17 Ibidem, t. 2, s. 177.

${ }^{18}$ E. Schure, Wielcy Wtajemniczeni, t. 1, Warszawa 1995, s. 5.

19 Tezy dogmatyczne Polskiego Kościoła Narodowego, GZ 1925, nr 12, s. 4.

20 V. Indra, Na temat: Co jest Prawda?, GZ 1925, nr 9, s. 5.

${ }^{21}$ Co to jest objawienie?, GZ 1925, nr 5, s. 2.

22 Ibidem.

${ }^{23}$ Dlaczego zerwaliśmy z Rzymem?, GZ 1925, nr 13, s. 3. Choć znowuż w innym miejscu przyznawał: ,[...] nie rościmy sobie pretensyi do [...] całkowitej znajomości Boga i jego tajemnic”. V. Indra, Co to jest Pismo św.?, GZ 1925, nr 8, s. 5.

${ }^{24}$ Glówne zasady Polsko-Katolickiego Kościoła Narodowego w Dąbrowie Górn., GZ 1925, nr 12, s. 4.

25 Jeden z wielu, Kościół a Sprawa Społeczna, GZ 1925, nr 21, s. 10.

${ }^{26}$ Poradnik rolniczy, GZ 1925, nr 13, s. 6.

${ }^{27}$ Kościót a kwestja spoteczna, GZ 1924, nr 2, s. 5.

${ }_{28}$ Poradnik rolniczy, GZ 1925, nr 13, s. 6. 
jako duch ucieleśniony [...] jest doczesny”29. Huszno zapowiadał: „I stanie się, że [...] duch będzie człowiekiem, a człowiek duchem, stanowiąc sobą rodzaj świętych w Królestwie Bożym"30.

Uświęcenie doczesności prowadziło do wniosku, że ,[ż]ycia pozagrobowego nie należy szukać gdzieś w zaświatach, ale tu na ziemi”’31. Według Huszny, o ile zmarłym - w sensie duchowym - jest człowiek grzeszny, to zmartwychwstanie polega na poznaniu Boga. Owo zmartwychwstanie duchowe - poznanie Prawdy - musi poprzedzać zmartwychwstanie fizyczne (zdaniem niekonsekwentnego tu Huszny wynika to z władzy ducha nad materią); doskonali ludzie będą mogli wówczas przewidywać przyszłość, teleportować się, lewitować, porozumiewać się telepatycznie itd. ${ }^{32}$

Mamy tu do czynienia $\mathrm{z}$ terrestrializacją eschatologii (określenie Andrzeja Walickiego $)^{33}$.Zaświaty okazują się formami otaczającej nas rzeczywistości. „, $[\mathrm{N}]$ iebo, piekło, czyściec, otchłań nie oznaczają jakiegoś innego poza naszym światem miejsca, ale różne stany świata naszego [...]. Świat nasz obecny jest otchłanią, piekłem, czyśćcem a będzie niebem [...] dla tych, którzy Prawdę objawioną przez P.K.K.N. przyjmą" - głosiły dogmaty PKKN ${ }^{34}$. Niebo miało według Huszny dwojakie, a faktycznie trojakie znaczenie. Po pierwsze, miała to być - fizycznie - kopuła nieba: „,szata, która okrywa Boga”. Po drugie, pojęcie nieba funkcjonuje w znaczeniu duchowym jako indywidualne oświecenie: „Do nieba wstępuje, kto uchyla [tę - J.T.] zasłonę [...]”, „kto Boga-Prawdę poznaje”. Po trzecie wreszcie, niebo - jako stan rajski - okazuje się mieć wymiar społeczny. To przyszłe Królestwo Boże na ziemi, w którym „,[w]ładza [...] w ręku Boga i świętych Jego spoczywa. Niema tu wojen ani zbrojeń, [...] niema ucisku ani wyzysku", ani ciężkiej pracy, ludzie mocą modlitwy władają żywiołami, panuje miłość powszechna i „szczęście niewymowne”"35.

Piekło i czyściec zostały całkowicie przeniesione w doczesność ${ }^{36}$. Huszno pisał o piekle, jakie stwarza na ziemi niewola polityczna, ekonomiczna i duchowa ${ }^{37}$; „bramy piekła” w jego ujęciu to „mocarze starego świata” ${ }^{38}$. Dla oświeconych wszakże, świadomych drogi wyzwolenia doczesność jest czyśćcem ${ }^{39}$. „[Ś]wiat jest jeden i [...] czyśćca nie należy szukać gdzieś w zaświatach, bo go mamy tu na ziemi”,

${ }^{29}$ O życiu poza grobem, GZ 1925, nr 23, s. 14.

${ }^{30}$ V. Indra, O wtadzy, GZ 1925, nr 12, s. 7.

31 O żciu poza grobem, GZ 1925, nr 23, s. 13.

${ }^{32}$ Dwojakie zmartwychwstanie, GZ 1925, nr 11, s. 4.

${ }_{33}$ A. Walicki, Millenaryzm i mesjanizm religijny a romantyczny mesjanizm polski: zarys problematyki, „Pamiętnik Literacki” 1971, nr 4, s. 43.

${ }^{34}$ Tezy dogmatyczne Polskiego Kościoła Narodowego, GZ 1925, nr 12, s. 6.

35 V. Indra, O niebie, GZ 1925, nr 13, s. 3. W tym samym (!) artykule odnajdujemy jednak jeszcze inną interpretację tego pojęcia - cały świat współczesny urządzony jest na wzór greckiego Hadesu, a w nim ,„d]uchy sprawiedliwych zajmują niebo czyli elizyum, a duchy niesprawiedliwych Tartarum czyli dno piekła [...], mocni, [...] bogaci zajmują górę, słabi, prości, ubodzy - dół”. Ibidem.

${ }^{36}$ Co znaczy Niepokalane poczęcie Maryi Panny?, GZ 1924, nr 1, s. 5.

37 Od Redakcji stowo wstępne, GZ 1924, nr 1, s. 2.

${ }_{38}$ Św. Piotr-Opoka, GZ 1925, nr 16, s. 2.

39 V. Indra, O piekle, GZ 1925, nr 17, s. 4. 
pisał Huszno ${ }^{40}$. To już tu i teraz swym codziennym trudem i niedolą wierni odkupują przeszłe i obecne grzechy. Nietrudno dostrzec, że taka interpretacja eschatologii najbardziej przemawiała do proletariuszy będących parafianami Huszny.

Terrestrializacji uległy też jestestwa duchowe. „Człowiek żyjący jest duszą i duchem" "41, zatem aniołowie są po prostu ludźmi wolnymi od grzechu, których charakteryzują czystość i doskonałość w pojmowaniu Boga. Ba - każdy człowiek ma swego anioła stróża w tym sensie, że sam jest aniołem! ${ }^{42}$ Zarazem Huszno odwraca twierdzenie o demonach: skoro diabeł jest dręczycielem, to dręczyciel jest diabłem ${ }^{43}$. Diabłami są ludzie, którzy uciskają innych ${ }^{44}$, a więc walcząc z ludźmi złymi, walczy się ze złymi duchami, z szatanem ${ }^{45}$. Ich uosobieniem był Herod ${ }^{46}$. Nie chodzi tu jednak tylko o historycznego władcę Judei, ale o cały establishment ekonomiczny, polityczny i kościelny. „W Herodzie widzimy urzędowych przedstawicieli władzy jużto duchownej, jużto świeckiej starego kościoła, starego świata", którzy ignorują Boga i jego prawo ${ }^{47}$.

Od ezoteryków Huszno przejął cykliczną wizję historii w miejsce judeochrześcijańskiej koncepcji czasu linearnego ${ }^{48}$. Bławatska głosiła ,absolutną wszechświatowość prawa okresowości” ${ }^{49}$, Rudolf Steiner uważał, że zarówno „duchowe jestestwo człowieka wielokrotnie może przybierać postać cielesną”, jak i cała „Ziemia jest [...] powtórnym wcieleniem jakiejś wcześniej istniejącej planety" ${ }^{50}$. Tym śladem szedł także Huszno głoszący ,prawo wiecznych powrotów"51. Przemijanie uzasadniał cyklicznością: „,...] świat to wielkie kolisko, które wiecznie się obraca"52. Powtarzając poglądy innego okultysty - Giordana Bruno - twierdził, że świat jest wieczny, nie ma początku ani końca ${ }^{53}$. Tezy dogmatyczne Polskiego Kościoła Narodowego stanowiły: ,[...] to, co było niegdyś, [...] teraz jest, a co będzie, już było, albowiem

40 Młody kapłan, który zmartwychwstaje jako młoda dziewczyna, GZ 1925, nr 7, s. 8.

41 V. Indra, O aniołach $i$ djabłach, GZ 1925, nr 15, s. 6.

${ }^{42}$ Kult aniołów $i$ świętych, GZ 1925, nr 21, s. 3. W „Głosie Ziemowida” napotykamy też wzmianki, że „boskość leży w nas” (Jeden z wielu, Kościół a Sprawa Społeczna, GZ 1925, nr 21, s. 11) i człowiek jest w stanie własnym wysiłkiem ją osiągnąć („I ożył człowiek. [...] / Przejrzał na oczy. [...] / Stał się Mocarzem i Siłą. / [...] Z niewoli się ziemi wyzwolił" [Joannes, Szlakiem Ducha, GZ 1925, nr 10, s. 3]). Świadczyłoby to o obecności w PKKN skłonności do autoapoteozy (lub jak nazwał to M. Gardell: self-theomorhosis), deifikacji człowieka. Por. M. Gardell, Gods of the Blood. The Pagan Revival and White Separatism, Durham-London 2003, s. 291-292.

43 V. Indra, O piekle, GZ 1925, nr 17, s. 4.

44 Od Redakcji słowo wstepne, GZ 1924, nr 1, s. 2.

${ }^{45}$ Młody kapłan, który zmartwychwstaje jako młoda dziewczyna, GZ 1925, nr 7, s. 8.

46 Hymn P.K.K. Narodowego, GZ 1925, nr 9, s. 2.

${ }^{47}$ Boże Narodzenie: co znaczy, kiedy było i gdzie? (c.d.), GZ 1925, nr 6, s. 3.

48 Problem różnych koncepcji czasu przedstawia w całej jego złożoności Z. Danielewicz, Nie taki prosty. Meandry linearnej koncepcji czasu w chrześcijaństwie, „Studia Koszalińsko-Kołobrzeskie” 2015, nr 22, s. 229-242.

49 H. Bławatska, op. cit., t. 1, s. 47.

50 R. Steiner, Wiedza Tajemna czyli Poznanie wyższych światów, Gdynia 1992, s. 56, 59.

51 Adwent nowej ery, GZ 1924, nr 1, s. 2.

52 V. Indra, O niebie, GZ 1925, nr 13, s. 3.

53 Symbolika Pism świętych, GZ 1925, nr 15, s. 4; V. Indra, Michał Archaniot, GZ 1925, nr 22, s. 2. 
Bóg odnawia to, co przeminęło"54. Poszczególne cykle (ery), przez Husznę zwane czasem po prostu ,światami”, miały trwać po 6-12 tysięcy lat ${ }^{55}$. Każdy zaczynał się Złotym Wiekiem ${ }^{56}$, ziemskim Rajem, w którym ludzie byli aniołami ${ }^{57}$, potem jednak nadchodził czas upadku. „Kiedy [...] ludzkość [...] siebie stawia na równi z Bogiem, wtedy grzeszy pychą”, pisał „Głos Ziemowida”58, uznając to za bunt upadłych aniołów ${ }^{59}$. W swej schyłkowej fazie świat ulega skażeniu, „ludzkość straciwszy łaskę zmartwychwstania, wraz z nią utraci i tą moc cudowną" ${ }^{60}$ i odtąd podlega prawom przyrody ${ }^{61}$. Degeneracja odzwierciedla się też w stosunkach społecznych: zanika miłość Boga i bliźniego, panują pycha, samolubstwo i brutalnośćc ${ }^{2}$.

Jednak upadek - choć nieuchronny - nie jest nieodwracalny. „[K]ażdy świat, będąc tylko jednym z wielu światów [...] ma swój okres nocy ducha, okres postu i utrapienia" ${ }^{63}$, po którym nadchodzi odrodzenie. W ten sposób ,[o]bjawienie dawne jest ojcem objawienia nowego"64. Huszno wierzył, że obecnie żyjemy na przełomie czasów, ,w przededniu [...] Sądu Bożego nad światem i na świtaniu [...] Królestwa Bożego na ziemi" ${ }^{65}$, dlatego wzywał wiernych do pokuty ${ }^{66}$. Jego swoisty wariant millenaryzmu łączył w zaskakujący sposób elementy chrześcijańskie i hinduistyczne: „Żyjemy [...] w oczekiwaniu na przyjście Ramy nowego, który był i który przyjść ma. O przyjdź Panie Jezu!" 67.

Kosmicznej cykliczności światów w skali jednostkowej odpowiadała wędrówka dusz - ,zasada wiecznych przeistoczeń człowieka, jako duchowej treści, dla której ciało nasze jest jak ubranie" 68 . Huszno głosił, że człowiek żyje nieskończoną liczbę razy $^{69}$. Uważał naturalną śmierć za pożądaną, gdyż umiera się po to, aby się znowu narodzić: „Trumna jest siostrą kolebki”"70. Myśl tę rozwijały Tezy dogmatyczne Polskiego Kościoła Narodowego: „,[...] my żyliśmy już niegdyś, [...] i nieraz jeszcze żyć będziemy w przyszłych światach, a warunki życia naszego obecnie są zapłatą względnie karą za życie nasze poprzednie"71.

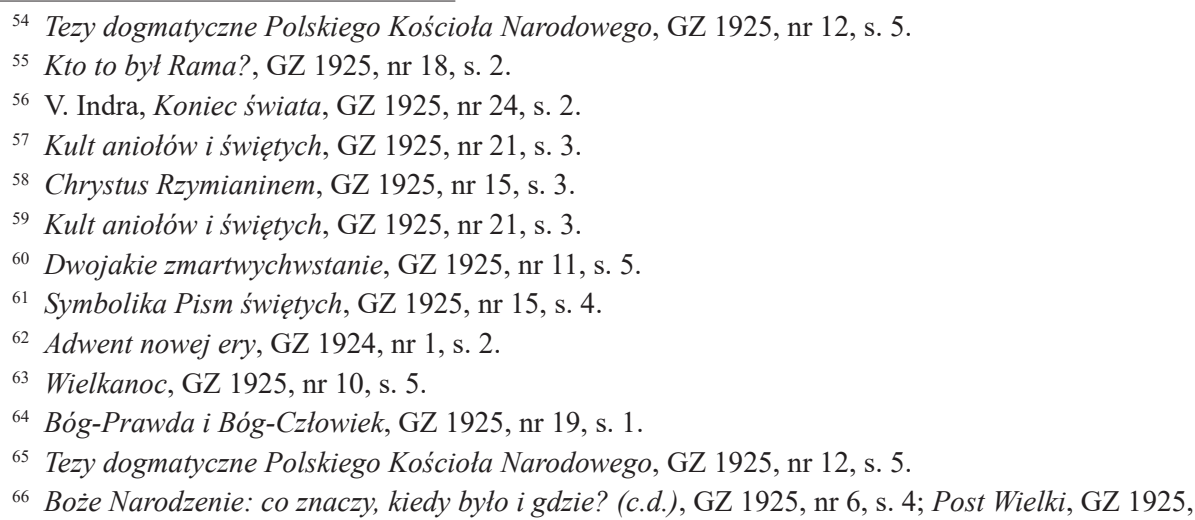
nr 8, s. 2.

67 V. Indra, Co rozumiemy pod stowem - Bóg?, GZ 1925, nr 7, s. 4.

68 Jeden z wielu, Kościół a Sprawa Społeczna, GZ 1925, nr 21, s. 10.

69 V. Indra, O piekle, GZ 1925, nr 17, s. 4.

70 O ̇̇yciu poza grobem, GZ 1925, nr 23, s. 13.

71 Tezy dogmatyczne Polskiego Kościoła Narodowego, GZ 1925, nr 12, s. 5. Huszno mgliście przewidywał też jednak przerwanie owego kołowrotu wcieleń: „Mieć wieczne odpocznienie, to znaczy być 
Ezoteryczne skłonności Huszny w pełni uwidoczniały się w jego sposobie odczytywania dogmatów, przypowieści i symboli. Swoisty alegoryzm - „, [s]ymboliczne [...] tłomaczenie Pism św. symbolu wiary, liturgji, sakramentów i dogmatów"72 stał się jednym z pryncypiów PKKN. Takie podejście pozwalało Husznie na łączenie ludowej religijności swych parafian, przywiązanych do katolickiej obrzędowości, z ezoteryczną wykładnią prawd wiary. „My z tego [nauk Kościoła rzymskokatolickiego - J.T.] nic nie odrzucamy, [...] wlewamy tylko w stare formy nową treść", pisał „Głos Ziemowida”73. W Tezy dogmatycznych Kościół Narodowy potwierdzał, że uznaje kanon ksiąg świętych, symbol wiary i liturgię w znaczeniu symbolicznym ${ }^{74}$.

Wynikało to z przeświadczenia Huszny, że chrześcijaństwo jest „syntezą wiedzy tajemnej, wiedzy Bożej [...], drogą tradycji przekazaną z tego czasu, kiedy ziemia $[\ldots]$ była [...] Królestwem Bożym"75. Zarazem jednak Kościoły współczesne, kurczowo trzymając się formy dawnych wierzeń, straciły umiejętność rozumienia symboli religijnych ${ }^{76}$. Huszno przyznawał, że „Kościół rzymski jest pedantycznym konserwatorem prawd odwiecznych", ale odczytując je dosłownie, gubi ich rzeczywiste znaczenie ${ }^{77}$. Tymczasem „historja święta jest [...] obrazowo podaną historją światów minionych, które były przed naszym światem"78. Podkreślał wszakże, że Pismo Święte podaje prawdy wieczne nie wprost, lecz alegorycznie ${ }^{79}$. Oświecony nie może negować autorytetu Pisma, ale prostactwem i naiwnością byłoby dosłowne odczytywanie tegoż. „Pisma św. i Liturgie kościelne są dla nas tem, czem pomoce naukowe dla ucznia. [...] cieniem, obrazem, podobieństwem, pamiątką Boga-Prawdy, i tylko pomagają nam poznać tajemnice bytu i Boga"80. By dotrzeć do ukrytego sensu duchowego, nie wystarczy rozumowa analiza - „trzeba mieć Ducha Bożego”, dlatego interpretacja świętych ksiąg zarezerwowana jest dla jedynego prawdziwego kościoła: PKKN ${ }^{81}$. Wtedy „martwe symbole zaczynają [...] przemawiać głębią swej treści ezoterycznej”"82.

Nie tylko chrześcijaństwo wymagało pogłębionego, alegorycznego odczytania, ale też inne religie. „Wszystkie mitologie świata zasadniczo się między sobą niewiele różnią. Różnica polega na wielości [...] symboli i imion Bożych”"83, pisał „Głos Ziemowida”. Zwracając uwagę na podobieństwo chrześcijańskich i słowiańskich

wolnym od ustawicznych wcieleń". Młody kapłan, który zmartwychwstaje jako młoda dziewczyna, GZ 1925 , nr 7, s. 8.

${ }^{72}$ Glówne zasady Polsko-Katolickiego Kościoła Narodowego w Dąbrowie Górn., GZ 1925, nr 12, s. 2.

73 Symbolika Pism świętych, GZ 1925, nr 15, s. 4.

${ }^{74}$ Tezy dogmatyczne Polskiego Kościoła Narodowego, GZ 1925, nr 12, s. 6.

75 Boże Narodzenie: co znaczy, kiedy było i gdzie?, GZ 1924, nr 2, s. 4.

76 Boże Ciało, GZ 1925, nr 14, s. 2.

${ }_{77}$ Co znaczy Niepokalane poczęcie Maryi Panny?, GZ 1924, nr 1, s. 4.

${ }^{78}$ Boże Narodzenie: co znaczy, kiedy byto i gdzie? (c.d.), GZ 1925, nr 4, s. 4.

${ }^{79}$ Co znaczy Niepokalane poczęcie Maryi Panny?, GZ 1924, nr 1, s. 4.

${ }^{80}$ V. Indra, Na temat: Co jest Prawda?, GZ 1925, nr 9, s. 5.

${ }^{81}$ Idem, Co to jest Pismo św.?, GZ 1925, nr 8, s. 3.

${ }^{82}$ Boże Ciało, GZ 1925, nr 14, s. 1.

${ }^{83}$ Tajemnica Polski, GZ 1925, nr 7, s. 6. 
obrzędów, uznawał np. tożsamość chrześcijaństwa i pogańskich wierzeń Słowian ${ }^{84}$. Dogmatem PKKN była ,jedność Prawdy Bożej po przez wielką ilość figur"85. Głoszono, że Prawda jest jedna, ale ,wielorako uosobiona, [...] uplastyczniona, ze względu na kolejność objawień Boga-Prawdy”86. Jak wyjaśniano, „,[s]ymbol to [...] tylko cień prawdy. Symboli może być wiele jak cieni" ${ }^{\prime \prime}$, w rzeczywistości jednak „mamy przed sobą jeden przedmiot odbity w tysiącach zwierciadel”88. Huszno skrupulatnie (a nieraz na wyrost) wyszukiwał podobieństwa postaci, obrzędów i symboli różnych religii, konstruując długie i niekonsekwentne łańcuchy utożsamień.

Jedyny Bóg miał mieć wiele twarzy - to biblijny El, egipski Ra, germański Thor i inni. „Imion [...] wiele, ale Bóg jest jeden" ".9. Co więcej, miał występować też pod różnymi postaciami. $Z$ jednej strony Bóg to „absolut i byt doskonały, który jeden jest, dla którego świat cały jest [...] złudnym mirażem. Bóg-Duch, który przenika wszechświat i [...] wiecznie jest. Dla niego nie ma przestrzeni, ani czasu, ani ruchu, [...] nie zna żadnych przemian"90. Pojęcie Boga interpretowane było tu w duchu deistycznym, jako niezmienne wieczne prawo rządzące światem ${ }^{91}$. Ów Bóg Prawda okazywał się po prostu ideą, która się z Ducha Świętego poczyna w umyśle człowieka ${ }^{92}$. Poznanie Boga polegało na zrozumieniu praw kosmicznych.

Z drugiej wszakże strony Bóg objawiał się w formie fizycznej jako Bóg Człowiek, który jest „ciałem niejako i cieniem Boga-Prawdy”93. Taki „Bóg-Człowiek, którego [...] Duch Boży w odstępach wieków czyni swoim narzędziem [...] - rodzi się na świecie i żyje, i umiera, jak każdy człowiek”"94. „Głos Ziemowida” przyrównywał Boga do słońca, a jego ziemski awatar do ,zwierciadła, w którem odbija się jasność Boża"95. Bóg Człowiek był jednak niezbędnym ogniwem w procesie zbawienia nie przez swą odkupicielską mękę, ale przez naukę ${ }^{96}$. Do „Boga Prawdy” (k’Ra El) wiedzie ludzkość właśnie Król-Duch - Jezus Chrystus ${ }^{97}$.

Chrystus Huszny jednak niewiele miał wspólnego z tym chrześcijańskim. Duchowny pisał, że postacie historyczne jak Jezus czy Mahomet były tylko podobne „życiem swoim i czynami” do prawdziwego Syna Bożego, z którego „przyjściem złączony jest koniec starego świata i początek nowego" 98 . Skoro w I w. n.e. nie na-

${ }^{84}$ Współczesne pogaństwo, GZ 1925, nr 17, s. 2.

85 Co to jest ,, Glos Ziemowida”?, GZ 1925, nr 24, s. 15.

86 Bóg-Prawda i Bóg-Człowiek, GZ 1925, nr 19, s. 1.

87 Współczesne pogaństwo, GZ 1925, nr 17, s. 3.

${ }^{88}$ Hymn P.K.K. Narodowego, GZ 1925, nr 9, s. 2.

89 Co to jest objawienie?, GZ 1925, nr 5, s. 1.

90 V. Indra, Co rozumiemy pod stowem - Bóg?, GZ 1925, nr 7, s. 2.

91 Idem, Na temat: Co jest Prawda?, GZ 1925, nr 9, s. 5.

92 Bóg-Prawda i Bóg-Człowiek, GZ 1925, nr 19, s. 1; por. Co znaczy Niepokalane poczęcie Maryi Panny?, GZ 1924, nr 1, s. 5.

93 Bóg-Prawda i Bóg-Człowiek, GZ 1925, nr 19, s. 2.

94 V. Indra, Co rozumiemy pod słowem - Bóg?, GZ 1925, nr 7, s. 2.

95 Rezurekcja, GZ 1925, nr 10, s. 8.

96 V. Indra, Co rozumiemy pod stowem - Bóg?, GZ 1925, nr 7, s. 2.

97 Od Redakcji stowo wstępne, GZ 1924, nr 1, s. 1.

98 V. Indra, Co rozumiemy pod słowem - Bóg?, GZ 1925, nr 7, s. 3. 
stąpił sąd ostateczny (rozumiany jako „sąd Boży nad tyranami i gnębicielami ludu”) i ugruntowanie Królestwa Bożego na ziemi, w którym panują doskonała znajomość Boga, jedność, sprawiedliwość, pokój, miłość i długowieczność - to znaczy, że nie Chrystus wtedy nastał, a tylko po raz kolejny odrodziła się stara idea „Boga powracającego" $"$.

Chrystusem był pierwszym z synów Bożych. „Chrystus pierwszy był tym chrztem duchowym ochrzczony, to znaczy pierwszy poznał Ojca swego, Boga, przez co zwyciężył grzech" ${ }^{100}$. To oznacza, że kult imienia Jezus jest wieczny ${ }^{101}$, a nie osadzony w konkretnej historii. Huszno pisał, że „[p]ostać [...] Zbawcy-Człowieka była od wieków [...] powszechna [...] wszystkim narodom, rasom, krajom" ${ }^{102}$. Chrystusem mieli być więc Adam, Abel, Noe, Abraham, (Jakub) Izrael, Mojżesz, Dawid, Salomon, Józef, Jan, „założyciel rzymskiego chrześcijaństwa” Jezus (jednak!), a także Rama, Budda, Mahomet, Zeus, Jowisz, Światowid, Perun, Piast (Kołodziej) ${ }^{103}$, Michał Archanioł, Herakles, Samson, Ziemowid („arcykapłan ziemi”), Melchizedek, św. Jerzy ${ }^{104}$, Gilgamesz, Krak ${ }^{105}$, Allach $^{106}$, bodaj nawet Orfeusz, którego harfa utożsamiana była z Dawidową ${ }^{107}$.

Dlatego Huszno przestrzegał: „[...] daremnie Go [Chrystusa - J.T.] szukacie w [...] kościołach, bo te są grobem”108. Prawdziwy Chrystus to „Prawda żywa”, obecna w wielu osobach. Męka Chrystusa trwa przez całą historię świata, gdy wypaczana jest Jego nauka ${ }^{109}$; utożsamiana jest $\mathrm{z}$ walką archanioła Michała z szatanem, Ormuzda z Arymanem, Kraka ze smokiem wawelskim, Heraklesa z hydrą lernejską, Zeusa z gigantami - generalnie: z permanentną walką dobra ze złem, „, walką nowych odrodzonych i wtajemniczonych ludzi z kołtuństwem, bałwochwalstwem, pychą i zacofaństwem starego świata" ${ }^{110}$.

Jak wynikało z wywodów Huszny, w każdym cyklu dziejów świata Chrystus objawia się dwukrotnie: u jego zarania i końca. W naszym świecie pierwszym Zbawicielem miał być Rama, który „po ostatnim potopie” założył Kościół Boży ${ }^{111}$. Ów „Jezus-światłość [...] był Lechitą i na lackiej ziemi się narodził, z matki Lechitki

99 Boże Narodzenie: co znaczy, kiedy było i gdzie?, GZ 1924, nr 2, s. 4.

100 Co znaczy Niepokalane poczęcie Maryi Panny?, GZ 1924, nr 1, s. 5.

101 Do Siego Lata, GZ 1925, nr 3, s. 1.

102 V. Indra, Co rozumiemy pod słowem - Bóg?, GZ 1925, nr 7, s. 3.

103 Ibidem.

104 Hymn P.K.K. Narodowego, GZ 1925, nr 9, s. 2.

105 Kto to byt Rama?, GZ 1925, nr 18, s. 2.

106 Dar języków, GZ 1925, nr 13, s. 2.

107 V. Indra, O niebie, GZ 1925, nr 13, s. 3. Tylko pośród Słowian Chrystus występował jako Jesse Lado, Jasza, Eli, Iwan Kupała, Kolada, Ilja Muromiec. Tajemnica Polski, GZ 1925, nr 7, s. 6. Huszno pisał też o „Synu Człowieczym, który przez poznanie Boga staje się synem Bożym. Synem Bożym jest każdy człowiek, który [...] przyjmie [...] Prawdę Bożą". Bóg-Prawda i Bóg-Człowiek, GZ 1925, nr 19, s. 2. Ze sformułowania tego można wnosić, że perspektywa boskości otwarta jest dla wszystkich.

108 Chrystus zmartwychwstan jest!, GZ 1925, nr 10, s. 1.

109 Post Wielki, GZ 1925, nr 8, s. 1.

110 V. Indra, Michat Archaniot, GZ 1925, nr 22, s. 2.

111 Chrystus Rzymianinem, GZ 1925, nr 15, s. 2. „Rzymianie” to - zdaniem Huszny - po prostu wyznawcy Ramy. 
i ojca kapłana starego Kościoła, który był tym aniołem Gabryelem"112. Ponieważ nadchodziły czasy ostateczne, Chrystus objawić miał się ponownie. PKKN głosił: „Wierzymy w to, że z narodu polskiego przyjdzie nowy Zbawca świata, Chrystus, Król-Duch" "13. Dawał nawet pewne wskazówki na temat tożsamości nadchodzącego Zbawiciela: „adwent nowej ery” miał zacząć się w piętnastym roku pontyfikatu papieża Leona XIII ${ }^{114}$. W tym właśnie roku na świat przyszedł Andrzej Huszno ${ }^{115}$.

Wielość Synów Bożych pod znakiem zapytania stawiała chrześcijański trynitaryzm. Huszno oznajmiał więc, że Trójca Święta jest tylko „symbolem wielości”, w którym Ojciec i Syn symbolizują stary i nowy świat ${ }^{116}$.

Niewiele uwagi poświęcał Huszno osobie Matki Boskiej, tak wielką czcią otaczanej przez mariawitów. Pisał, że Maria jest tylko symbolem Chrystusowego człowieczeństwa, dlatego „w symbolu Niepokalanego Poczęcia Najśw[iętszej] Marji Panny czcimy nie żadną żydówkę [...], ale Boga samego, Chrystusa jako człowieka"117. Maria ulegała kompletnej depersonalizacji, okazała się „Kościołem Chrystusowym Matką Naszą" 118 .

W podobny sposób PKKN interpretował kult świętych. Zdaniem Huszny kult świętych jest kultem doskonałych przodków - tych, którzy „w czemkolwiek przypominali Chrystusa" ${ }^{119}$. Oznaczało to zanegowanie wartości katolickiego kultu świętych jako przemijającego i partykularnego, pozbawionego rzeczywistej wartości duchowej ${ }^{120}$. Duchowny przyznawał, że pomazańcy czasem ,zniżają się do [...] bałwochwalstwa", ale jak wyjaśniał, odsłaniając w ten sposób mimochodem socjotechnikę PKKN, „czynią to jedynie dla dobra zbłąkanych ludzi, aby ich oswoić”121.

W ujęciu Huszny również krzyż przestawał być jedynym i uniwersalnym świętym symbolem ${ }^{122}$. Wprawdzie duchowny uznawał, że krzyż to symbol bramy niebios, ale zarazem zrównywał krzyż ze swastyką (która „koło świata oznacza i jego nieskończone obroty”) i gwiazdą betlejemską - „gwiazdą wskazującą na Wschód słońca sprawiedliwości” ${ }^{123}$. Również ogień miał być symbolem „mądrości i mocy Bożej"124.

112 Kazanie ks. Huszny na 1-sza niedzielę Adwentu, GZ 1925, nr 1, s. 1.

113 Ibidem, s. 3.

114 Boże Narodzenie: co znaczy, kiedy było i gdzie? (c.d.), GZ 1925, nr 6, s. 2.

115 „Głos Ziemowida” pisał, że księdza Huszno „Bóg sam wybrał i łaską swą sprawił, że [...] przebudził się i poznał Boga-Prawdę". Powstań Ludu Polski!, GZ 1925, nr 12, s. 1. Zarazem jednak pisano, że PKKN poprzedza Kościół Boży jak Jan Chrzciciel poprzedzał Chrystusa: V. Indra, Co to jest Pismo św.?, GZ 1925, nr 8, s. 4.

116 V. Indra, O Tajemnicy Trójcy św., GZ 1925, nr 14, s. 3.

${ }^{117}$ Co znaczy Niepokalane poczęcie Maryi Panny?, GZ 1924, nr 1, s. 6. Być może wynikało to z przekonania Huszny, że „[k]obiecość oznacza słabą naturę ludzką”. Ibidem, s. 7.

118 V. Indra, Kult Marji Panny Matki Boga-Człowieka, GZ 1925, nr 20, s. 2.

119 Kult świętych, GZ 1925, nr 23, s. 2.

120 Ibidem.

${ }^{121}$ Kult aniołów i świętych, GZ 1925, nr 21, s. 3.

122 Jako ciekawostkę można dodać, że zdaniem Huszny Jezus został nie ukrzyżowany, a rozstrzelany z broni palnej. Tajemnica Krzyża, GZ 1925, nr 9, s. 4.

${ }^{123}$ Ibidem. Okładka publikacji Polski Kościót Narodowy ozdobiona była znakiem swastyki.

${ }^{124}$ Hymn P.K.K. Narodowego, GZ 1925, nr 9, s. 2. 
Symbolicznie interpretowane były w PKKN chrześcijańskie rytuały. Chrzest uważano za „symbol przeistoczenia Syna Człowieczego w Syna Bożego" ${ }^{125}$, msza to „pamiątka nauczania apostołów”, opłatek miał być jedynie „figurą Prawdy Bożej, a nie samym Bogiem"126.

Ciekawego zabiegu dokonywał Huszno w kalendarzu liturgicznym: zachowując wszystkie chrześcijańskie święta, interpretował je zarazem w duchu pogańskim, czyli odwracał inkulturacyjne działania Kościoła przed wiekami chrystianizującego pogan. Kwestionował historyczność Bożego Narodzenia w Palestynie, twierdząc, że „[u]roczystość Bożego Narodzenia [...] jest pamiątką [...] duchowych zaślubin Boga z ludzkością", do którego doszło w zaraniu ery ${ }^{127}$. Gwiazda betlejemska miała być aniołem, a trzej królowie to pasterze ludu - pierwsi wyznawcy Chrystusa, którzy dali początek pierwszym dynastiom panującym ${ }^{128}$. Święto Matki Boskiej Gromnicznej jest „pamiątką [...] spotkania dwóch światów”, które „odpowiada niejako początkowi sądu Bożego nad światem”129. Wielkanoc upamiętnia „zwycięstwo Prawdy-Chrystusa nad błędem-Szatanem”, przy czym „przyroda cała wtóruje tajemniczym obrzędom religijnym, przez zwycięstwo wiosny nad zimą"130. Adwent obchodzono na pamiątkę okresu ucisku przed tysiącami lat ${ }^{131}$. Mariya Lesiv określa takie prowadzące do deinkulturacji wnioskowanie jako antysynkretyzm ${ }^{132}$.

Koncepcji Huszny nie da się jednak sprowadzić do neopoganizmu. Fundamentem doktryny PKKN było przeświadczenie o istotowej jedności wszystkich religii. To było coś więcej niż współczesny posoborowy ekumenizm. Huszno głosił, że „wszystkie religje świata ze wspólnego i jednego źródła swój początek wiodą”, a „obrzędy kościelne i pisma święte wszystkich wiar t.zw. ortodoksyjnych zawierają w sobie jedną i tą samą prawdę, ukrytą tylko pod różnymi symbolami" ${ }^{133}$. Chrześcijaństwo miało jedynie powtarzać odwieczne prawdy głoszone wcześniej przez buddyzm czy mitraizm ${ }^{134}$. Powołując się na przypowieść o wieży Babel, twierdził, że pomieszanie języków w rzeczywistości oznacza rozdrobnienie wyznaniowe ${ }^{135}$, ale biblijne proroctwa zapowiadają powrót do pradawnej jedności przez stworzenie jednej uniwersalnej religii ${ }^{136}$. Już w 1918 r. Huszno głosił ogólnoludzki, wszechreligijny ekumenizm, obejmujący nie tylko różne odmiany chrześcijaństwa, ale też

125 V. Indra, Nowy Rok, GZ 1925, nr 3, s. 2.

126 Boże Ciało, GZ 1925, nr 14, s. 2.

127 Boże Narodzenie: co znaczy, kiedy było i gdzie?, GZ 1924, nr 2, s. 2.

128 V. Indra, Gwiazda Trzech Króli, GZ 1925, nr 4, s. 1-3.

129 Idem, Gromniczna, GZ 1925, nr 6, s. 1.

130 Wielkanoc, GZ 1925, nr 10, s. 4.

131 Powstań Ludu Polski!, GZ 1925, nr 12, s. 1.

132 M. Lesiv, Ukrainian Paganism and Syncretism: “This Is Indeed Ours!', [w:] Modern Pagan and Native Faith Movements in Central and Eastern Europe, K. Aitamurto, S. Simpson (red.), Durham 2013, s. $132-141$.

133 Tezy dogmatyczne Polskiego Kościoła Narodowego, GZ 1925, nr 12, s. 6.

134 V. Indra, Co rozumiemy pod stowem - Bóg?, GZ 1925, nr 7, s. 4.

135 Chrystus Rzymianinem, GZ 1925, nr 15, s. 3.

136 Dar języków, GZ 1925, nr 13, s. 1. 
judaizm, islam i buddyzm ${ }^{137}$. To właśnie zadaniem PKKN było religijne uzgodnienie i połączenie wyznań i narodów ${ }^{138}$ („odnaleźć jedność Prawdy Bożej w wielości osób, symboli i wiar, co utoruje nam drogę do jednego Kościoła - Państwa Ludzkości w Duchu” $\left.{ }^{139}\right)$. Dlatego „Głos Ziemowida” pracowicie odkrywał podobieństwa doktrynalne i obrzędowe różnych religii ${ }^{140}$.

Ideę wspólnego źródła wszystkich religii zaczerpnął Huszno od teozofów. Bławatska pisała: ,[...] filozofia ezoteryczna jedna wszystkie religie, obnaża je z ich [...] zewnętrznych szat, i wykazuje, że rdzeń każdej z nich jest identyczny z rdzeniem każdej innej wielkiej religii”, gdyż jej zasady są „tak stare jak myślący człowiek”141. Edward Schure głosił, że „religia odwieczna, religia wszechświata”, poznawana poprzez „prawdę ośrodkową”, ciągnie się od Ramy przez Hermesa, Mojżesza, Orfeusza, Pitagorasa i Platona po Chrystusa ${ }^{142}$.

Korzenie tej koncepcji sięgają jednak głębiej, do XV w., gdy kierujący Akademią Platońską we Florencji Marsilio Ficino (1433-1499) starał się wykazać zbieżność, jeśli nie tożsamość, platonizmu i chrześcijaństwa ${ }^{143}$. Ficino powoływał się na gnostyckie dzieło Corpus Hermeticum, uważając, iż pochodzi z czasów Mojżesza lub wcześniejszych ${ }^{144}$. W $1540 \mathrm{r}$. Augustyn Steuchus wprowadził pojęcie philosophia perennis (filozofia wieczysta), głosząc, że „tak jak istnieje tylko jedna zasada wszelkich rzeczy (ut unum est omnium rerum principium), tak samo wiedza o niej zawsze była u wszystkich ludzi ta sama (sic unam atque eandem de eo scientiam semper apud omnes fuisse)" ${ }^{\prime 45}$. Odkrycie przez Isaaca Casaubona w 1614 r., że Corpus Hermeticum zostało napisane między I a III w. n.e., załamało perenializm. Idea wspólnego źródła wszystkich religii przetrwała jednak na marginesie życia intelektualnego (m.in. w martynizmie), a w XIX w. odrodziła się w formie teozofii ${ }^{146}$. Koncepcje Huszny możemy więc uznać za rodzimy polski wariant perenializmu.

137 A. Huszno, Kościól demokratyczny, Kraków 1919, s. 16.

138 P. Włast, Co Polska ludzkości dać musi?, GZ 1925, nr 18, s. 5.

139 V. Indra, O Tajemnicy Trójcy św., GZ 1925, nr 14, s. 4.

${ }^{140}$ Co znaczy Niepokalane poczęcie Maryi Panny?, GZ 1924, nr 1, s. 7; Boże Narodzenie: co znaczy, kiedy było i gdzie?, GZ 1924, nr 2, s. 3. Dostrzegano podobieństwo nawet między chrześcijaństwem a religią Inków. W. Wójcik, Korespondencja z Brazylji, GZ 1925, nr 19, s. 4-7.

141 H. Bławatska, op. cit., t. 1, s. 10, 27.

${ }^{142}$ E. Schure, op. cit., passim. Według współczesnego polskiego perenialisty „,[p]oczątki Wiedzy Starożytnych sięgają - wedle naszych ustaleń - VI tysiąclecia przed Chrystusem. Jądrem tej Wiedzy jest nauka o Sekretnym Imieniu Jedynego Boga przekazana Adamowi, [...] od którego bierze początek łańcuch wtajemniczeń". J.W. Suliga, Wielcy Magowie Świata. Dzieje ezoterycznej tradycji Zachodu, t. I: Historia Przymierzy, Warszawa 1997, s. 30.

143 M. Sedgwick, Against the Modern World. Traditionalism and the Secret Intellectual History of the Twentieth Century, Oxford-New York 2004, s. 23-24.

${ }^{144}$ O doktrynie Hermesa Trismegistosa, twórcy Corpus Hermeticum, zob. H. Jonas, Religia gnozy, Kraków 1994, s. 163-188.

145 S. Wielgus, Philosophia Perennis, [w:] Powszechna encyklopedia filozofii, t. 10: Suplement, aut. haseł suplementu Marian Aleksandrowicz et al., zespół red. Andrzej Maryniarczyk et al., Lublin 2009, s. 332-334.

146 M. Sedgwick, op. cit., s. 40-47. 


\section{Bibliografia}

\section{Źródla}

„Głos Ziemowida” 1924-1935.

Huszno A., Kościót demokratyczny, Kraków 1919.

Huszno A., Polski Kościót Narodowy, jego historja, cel i zasady, Dabrowa Górnicza 1928.

Huszno A., Syn Człowieczy, Kraków 1917.

„Przegląd Powszechny” 1919.

„Wiadomości Archidiecezjalne Warszawskie” 1923.

\section{Opracowania}

Bławatska H., Doktryna tajemna, Warszawa 1996.

Boużyk M., Mitozofia czy bankructwo rozumu, „Człowiek w Kulturze” 1993, nr 1, s. 139-158.

Danielewicz Z., Nie taki prosty. Meandry linearnej koncepcji czasu w chrześcijaństwie, „Studia Koszalińsko-Kołobrzeskie" 2015, nr 22, s. 229-242.

Davis S.O., Mythosophy: The Wisdom of Myth. A Defense of Perennial Thought in Post-modern Times, mps, dysertacja doktorska, University of West Florida, 2001.

Gardell M., Gods of the Blood. The Pagan Revival and White Separatism, Durham-London 2003. Jonas H., Religia gnozy, Kraków 1994.

Jóźwiak W., W głąb mitologii Stowian, https://tarakablog.wordpress.com/2008/11/18/w-glab-mitologii-slowian/ [dostęp: 8.08.2015].

Kiereś H., Mit, [w:] Powszechna encyklopedia filozofii, t. 7, aut. haseł M. Aleksandrowicz et al., zespół red. A. Maryniarczyk et al., Lublin 2006, s. 279-280.

Lesiv M., Ukrainian Paganism and Syncretism: "This Is Indeed Ours!”, [w:] Modern Pagan and Native Faith Movements in Central and Eastern Europe, K. Aitamurto, S. Simpson (red.), Durham 2013, s. 132-141.

Schure E., Wielcy Wtajemniczeni, t. 1., Warszawa 1995.

Sedgwick M., Against the Modern World. Traditionalism and the Secret Intellectual History of the Twentieth Century, Oxford-New York 2004.

Sikorski T., Herezjarcha. Andrzej Huszno (1892-1939): życie - działalność - poglady, WarszawaRadzymin 2018.

Steiner R., Wiedza Tajemna czyli Poznanie wyższych światów, Gdynia 1992.

Suliga J.W., Wielcy Magowie Świata. Dzieje ezoterycznej tradycji Zachodu, t. I: Historia Przymierzy, Warszawa 1997.

Walicki A., Millenaryzm i mesjanizm religijny a romantyczny mesjanizm polski: zarys problematy$k i$, „Pamiętnik Literacki” 1971, nr 4, s. 23-46.

Waluszko J.P., Sarmacja, Mielec 1999.

Wielgus S., Philosophia Perennis, [w:] Powszechna encyklopedia filozofii, t. 10: Suplement, aut. haseł suplementu M. Aleksandrowicz et al., zespół red. A. Maryniarczyk et al., Lublin 2009, s. 332-334. 